\title{
REGIONAL FEATURES OF DEVELOPING COSSACK PUBLIC ASSOCIATIONS IN RUSSIAAND MAIN DIRECTIONS OF THEIR ACTIVITY (BASED ON THE REPUBLIC OF KALMYKIA) ${ }^{1}$
}

\author{
Nina G. Ochirova \\ Federal Research Centre The Southern Scientific Centre of the Russian Academy of Sciences (SSC RAS), \\ Rostov-on-Don, Russian Federation
}

\begin{abstract}
Introduction. The article considers the processes of socio-political, ethnocultural revival and the development of the modern Cossacks of Kalmykia. The paper deals with the activities of state authorities in reviving the Cossacks and the role of the Kalmyk Cossacks in the socio-cultural and socio-political processes of the region, interaction of local Cossack associations with Cossack communities not only in the south of Russia, but also in the country as a whole. Methods. The article uses the problem-chronological, historical-genetic, historiographical and source study analysis. Analysis. The author highlights the stages of developing the revival movement of the Kalmyk Cossacks: the first stage is the end of the 1980s and mid 1990s; the second stage is between the mid 1990s and mid 2000s: the third stage is from the mid 2000s until now. The author concludes that the processes of revival of Kalmyk Cossacks have their own specificity and features. First of all, the processes of revival took place outside their traditional territory of residence. Secondly, the union managed to gather immigrants from various hosts - the Don, Astrakhan, Kuban, Orenburg, Ural, Terek ones - in the Kalmyk Cossack district. Thirdly, a distinctive feature is peaceful coexistence of two equal denominations professed by the Kalmyk Cossacks - Buddhism and Orthodoxy. The author notes that the process of forming the Cossacks in the region was influenced both by the all-Russian tendencies of the Cossack revival and by the support of the regional political elite. However, such factors as organization and responsibility of Cossack associations, active citizenship, protecting their corporate interests also played an important role in the processes of revival and developing the Cossacks of the republic. Results. Thus, the Cossacks of Kalmykia became an integral part of the social structure of the republic. The Cossacks actively participate not only in the social and political processes, but also in the sphere of patriotic education of young people, regulating and controlling interethnic and interfaith conflicts in the region. Over the period of its existence, the Cossacks managed to gain prestige, become a significant social and political force in Kalmyk society.

Key words: Kalmykia, Don Kalmyk Cossacks, history, culture, social organization, government bodies, patriotism, revival.

Citation. Ochirova N.G. Regional Features of Developing Cossack Public Associations in Russia and Main Directions of Their Activity (Based on the Republic of Kalmykia). Vestnik Volgogradskogo gosudarstvennogo universiteta. Seriya 4. Istoriya. Regionovedenie. Mezhdunarodnye otnosheniya [Science Journal of Volgograd State University. History. Area Studies. International Relations], 2019, vol. 24, no. 4, pp. 191-201. (in Russian). DOI: https://doi.org/10.15688/jvolsu4.2019.4.16
\end{abstract}

\section{РЕГИОНАЛЬНЫЕ ОСОБЕННОСТИ ВОЗНИКНОВЕНИЯ КАЗАЧЬИХ ОБЩЕСТВЕННЫХ ОБЪЕДИНЕНИЙ В РОССИИ И ОСНОВНЫЕ НАПРАВЛЕНИЯ ИХ ДЕЯТЕЛЬНОСТИ (НА ПРИМЕРЕ РЕСПУБЛИКИ КАЛМЫКИЯ) ${ }^{1}$}

\author{
Нина Гаряевна Очирова \\ Федеральный исследовательский центр Южный научный центр Российской академии наук, \\ г. Ростов-на-Дону, Российская Федерация
}


Аннотация. В статье анализируется процесс возрождения и развития современного казачества Калмыкии как специфической части гражданского общества. Калмыки-казаки, являясь неотъемлемой частью калмыцкого народа, на протяжении трех столетий находились в составе Донского казачества. Они были одними из первых российских казаков-инородцев. Постоянные угрозы на юге Российского государства со стороны соседних восточных стран и Польши требовали защиты и укрепления его границ. Согласно договору о военном союзе с Россией в 1657 г. эти функции приняли на себя калмыки, чьи воинские доблести были широко известны. Из различных улусов калмыцких степей для защиты южных границ на Дону собиралось калмыцкое воинство. Часть людей оставалась, а другие снова откочевывали в родные места. С этого периода начиналась история калмыцкого казачества. Процессы реформирования и модернизации российского общества в конце 80-90-х гг. прошлого века создали объективные предпосылки к активной общественной деятельности казачества. В ноябре 1989 г. в республике состоялся 1-й Круг Союза казаков Калмыкии (далее - СКК), избравший атамана и правление. Первым атаманом возрождающегося казачества стал М.Г. Дженгуров, потомственный казак, прошедший большую школу жизни, авторитетный и энергичный. Анализ деятельности СКК, ныне Калмыцкого Казачьего Округа «Всевеликого войска Донского», за прошедший период раскрывает особенности и специфику возрождения калмыцкого казачества.

Ключевые слова: Калмыкия, донские калмыки-казаки, история, культура, общественная организация, органы власти, патриотизм, возрождение.

Цитирование. Очирова Н. Г. Региональные особенности возникновения казачьих общественных объединений в России и основные направления их деятельности (на примере Республики Калмыкия) // Вестник Волгоградского государственного университета. Серия 4, История. Регионоведение. Международные отношения. -2019. - Т. 24, № 4. - C. 191-201. -DOI: https://doi.org/10.15688/jvolsu4.2019.4.16

Введение. Происходящие в последние десятилетия процессы глобализации, охватывающие все сферы жизни российского общества, настоятельно требуют переосмысления многих из устоявшихся положений отечественной исторической науки. Одной из важнейших составляющих становления структуры современного общества и российской государственности стало активно развивающееся движение казачества за возрождение. Казачество Калмыкии имеет длительную историю в составе Донского казачества, с 1862 г. в правовом отношении калмыки-казаки были приравнены с казачеством Дона. Исторический анализ показывает, что приволжские калмыки были представлены также и в астраханском казачестве на всех этапах его истории. Вместе с тем калмыки-казаки всегда были неотъемлемой частью калмыцкого народа. В этой связи важно иметь полную и объективную картину истории казачества России как в целом, так и в ее регионах.

Актуальность рассматриваемой темы обусловлена как современным положением казачества в нашей стране, возрождение которого в значительной степени активизировалось в конце XX - начале XXI в., так и все возрастающим интересом ученых и общественности к наиболее проблемным аспектам истории казачества. На современном этапе изучение истории этнических и социальных групп населения Юга России, к которым относится и калмыцкий этнос, особенно актуализирует данную проблему ввиду сложности развития социальных процессов и вовлеченности казачества в политизацию межэтнических отношений.

Цель работы заключается в объективном исследовании содержания, конкретных форм деятельности СКК и эволюции социально-политического и этнокультурного процесса возрождения казачества Калмыкии, его особенностей на современном этапе. Цель исследования предопределила решение следующих задач: комплексно рассмотреть и проанализировать процесс возрождения калмыцкого казачества, его локальные особенности и региональную специфику с опорой на новейшие научные исследования в этой области, основываясь на вновь выявленных архивных и иных источниках; изучить и осветить деятельность государственных органов власти по возрождению казачества во взаимодействии с казачьими обществами; показать роль и место казачества Калмыкии в социально-культурных и общественно-политических процессах региона.

Методы и материалы. Основными методологическими принципами исследования являются научная объективность, выра- 
зившаяся в привлечении максимально возможного количества источников и системном подходе к анализируемому материалу, рассматриваемому во взаимосвязи всех составляющих элементов, а также принцип историзма, когда объект рассматривается в определенном историческом контексте. В работе применялись проблемно-хронологический, цивилизационный, историко-генетический, историографический и источниковедческий анализ. Именно эти принципы и методы дают возможность решать поставленные в работе задачи.

Эмпирическую основу работы составила достаточно широкая источниковая база, включающая в себя опубликованные и неопубликованные архивные материалы, в том числе из фондов Национального архива Республики Калмыкия, а также публикации в СМИ и электронные ресурсы. Важным источником послужили законодательные и нормативные акты федеральных и региональных органов государственной власти. Дополнительным источником работы стал личный опыт автора и впечатления, полученные в процессе совместной деятельности с общественными организациями, в том числе с казачеством Калмыкии на начальном этапе его формирования и движения к возрождению.

Изучение историографии рассматриваемой проблемы свидетельствует о внушительном росте публикаций, посвященных различным аспектам истории казачества, что связано, прежде всего, с начавшимся в конце 80-х гг. прошлого столетия бурным процессом активного возрождения казачества. Среди них - работы Г.Г. Матишова [13], П.Н. Краснова [11], Т.В. Таболиной [23], Н.Ф. Бугая [1], А. И. Козлова [10], Ю. И. Юрченко [27], Г.О. Мациевского [14], М.А. Рыбловой [21], О.В. Рвачевой [20], Хеге Тойе [29], А.Ю. Перетятько и Т.Э. Зульфугарзаде [28] и др. Важным вкладом в исследование истории казачества стала коллективная монография «Очерки истории и культуры казачества Юга России» под редакцией Г.Г. Матишова, И. О. Тюменцева [17]. Проблемам казачества Калмыкии посвящены работы К.П. Шовунова [26], К.Н. Максимова [12], У.Б. Очирова [18], В.Т. Тепкеева [24]. Эта тема отражена в отдельных публикациях Э.-Б.М. Гучиновой, С.Д. Таванец [3], А.М. Джалаевой [4] и др.
Анализ. В Республике Калмыкия процесс возрождения казачества начался задолго до того, как в Москве собрался I Учредительный Круг Союза казаков России. Уже в ноябре 1989 г. казаки Калмыкии провели первый Круг, избрав на нем атаманом потомственного казака М.Г. Дженгурова и правление, в которое вошли наиболее авторитетные и активные казаки.

30 июня 1990 г. в Москве состоялся I Учредительный Круг Союза казаков России, на котором казачество Калмыкии представляли атаман М.Г. Дженгуров, ученый-историк К.П. Шовунов и депутат Верховного Совета РСФСР К.Н. Илюмжинов. В состав правления Союза казаков России был избран К.Н. Илюмжинов, возглавивший посольскую палату [6].

После возвращения калмыцкой делегации из Москвы в августе 1990 г. был проведен I Учредительный Круг Союза казаков Калмыкии, который подтвердил статус атамана М.Г. Дженгурова и принял решение «О возрождении 13 традиционных донских станиц и избрании их атаманов» [7].

Одной из особенностей возрожденческого движения калмыцких казаков являлось то, что эти процессы происходили не на территории их исконного места проживания (Ростовской области), а в пределах Калмыкии. Поэтому возрождение станиц и хуторов было скорее символическим актом, не носившим в себе никаких обязательств как со стороны жителей поселков, которые именовались станицами, так и для казаков. Эта работа согласовывалась Союзом казаков с жителями населенных пунктов и местными органами исполнительной власти. Следует отметить, что Союз казаков Калмыкии с самого начала формировался как интернациональное сообщество, объединенное идеей возрождения славных традиций предков, но основной костяк его составляли калмыки и русские - потомки донских, астраханских, оренбургских, терских и других казаков. В августе 1990 г. в Союзе казаков Калмыкии на учете состояло 210 человек. В 1991 г., после смерти атамана М.Г. Дженгурова, сыгравшего важную роль в реализации идей возрождения казачества и создании региональной общественной организации, состоялся 2-й Круг Союза казаков Калмыкии, избравший новым атаманом Ю.Э. Хахулова. 
Происходившие в этот период в стране судьбоносные события, связанные с распадом СССР, сменой государственного строя, в значительной мере сказались на активности граждан, в том числе и в Калмыкии. В республике насчитывалось более 10 общественных объединений и движений. Среди них были оппозиционные силы, накалявшие обстановку и создававшие напряженную ситуацию, добивавшиеся отставки руководства республики и др. В это непростое время казаки Калмыкии участвовали в разрешении различных конфликтов, содействовали в сохранении стабильности в регионе, занимались оказанием помощи сотрудникам правоохранительных органов в перекрытии административных границ с южными регионами, гдепериодически происходили столкновения на межнациональной почве, шла борьба с терроризмом. В 1992 г. калмыки-казаки вместе с председателем Совета стариков Н.Д. Илюмжиновым выезжали в г. Георгиевск и принимали участие в улаживании разногласий между местными казаками и работниками районного отдела внутренних дел. В числе первых казаки Калмыкии во главе с войсковым атаманом прибыли на помощь низовым казакам Терека, когда на г. Кизляр напала банда Радуева. 26 апреля 1991 г. Верховным Советом РСФСР был принят «Закон о реабилитации репрессированных народов» [22]. Значение данного Закона для калмыков-казаков заключалось в том, что они в свое время были подвергнуты двойной репрессии (по национальному признаку и как казаки), а затем одним Законом реабилитированы. Вместе с тем данный Закон не в полной мере оправдал надежды казаков, как и ожидания всех репрессированных народов.

В мае 1992 г. на 3-м Круге казачества Калмыкии атаманом Союза казаков Калмыкии был избран П.Н. Шарманжинов, затем были обсуждены вопросы дальнейшего развития возрождения казачества, намечены мероприятия по укреплению и привлечению в организацию новых членов из числа потомков казаков. С этого времени деятельность казачества стала носить более конкретный характер, активизировалась работа в низовых звеньях, повысилась ее эффективность. Этот период в жизнедеятельности казачества отмечен началом реорганизации и структуриро- вания общественной организации по округам, станицам и хуторам ${ }^{2}$.

Республиканские и местные органы власти с самого начала деятельности казачьего движения содействовали его возрождению. Это было связано и с тем, что ряд руководителей различного уровня были потомками казаков и, несмотря на смену трех поколений, после «расказачивания» и репрессивной политики государства в отношении казаков в них сохранились дух казачества, историческая память. Многие из них входили в состав казачьего общества, оказывали спонсорскую помощь, способствовали созданию коммерческих структур. Казаки активно участвовали практически во всех мероприятиях, проводимых в республике, пропагандировали идеи возрождения казачества, занимались благотворительной деятельностью.

В начале 1993 г. законодательный орган Республики Калмыкия объявил о проведении выборов Президента РК, в связи с этим деятельность СКК возрастает и приобретает ярко выраженный политический характер. Союз казаков выдвигает кандидатуру К.Н. Илюмжинова, потомственного казака, на должность Президента Республики Калмыкия - Хальмг Тангч. Агитируя за него, члены СКК встречаются с избирателями в районах и г. Элисте, посещают учебные заведения, трудовые коллективы, знакомя их с историей казачества, программой кандидата в Президенты РК. Состоявшиеся 5 апреля 1993 г. выборы Президента Республики Калмыкия принесли победу К.Н. Илюмжинову и в значительной мере укрепили позиции казачества в социальной и общественно-политической сферах калмыцкого общества.

В июне 1994 г. в с. Приютном Приютненского района состоялся IV Круг, СКК, принявший решение о его реорганизации в Казачье войско Калмыкии (далее - КВК). Первым войсковым атаманом на нем был избран П.Н. Шарманжинов. В работе Круга принимал участие Президент Республики Калмыкия К.Н. Илюмжинов, выступивший и огласивший Указ «О Государственном Комитете по делам казачества Республики Калмыкия» от 6 июня 1994 г. № 107 [25]. Комитет стал одним из первых государственных структур по казачеству на Юге России и имел важное зна- 
чение в деле возрождения казачества в регионе. Новой государственной структуре казачества было выделено помещение, автотранспорт и созданы другие условия для его деятельности. Штатная численность составляла 5 человек, были введены должности председателя и заместителя председателя. Председателем Комитета был назначен П.Н. Шарманжинов с сохранением статуса атамана КВК. Указом было утверждено Временное положение о Госкомитете, в котором были определены его функции и задачи: осуществление исполнения государственной политики по вопросам казачества на территории Калмыкии; изучение и оказание помощи возрождению традиционного хозяйственного уклада жизни казачества; разработка поэтапной программы экономического и культурного возрождения казачества; внесение совместно с местными органами предложений о войсковом учете и подготовке казаков к военной службе и др. [2].

Таким образом, полномочия Комитета были достаточно широкими, казачество региона получило реальный рычаг для осуществления целей и задач своего движения за возрождение.

Важным законодательным актом явилось принятие Народным Хуралом (Парламентом) РК Закона Республики Калмыкия «О казачестве» [5]. Этот закон так же, как и вышеупомянутый указ Президента Республики Калмыкия, вышедший в 1994 г., о Госкомитете по казачеству в значительной степени опережал выход аналогичных документов в других субъектах Российской Федерации. Принятие данного Закона было своевременным, он определял основные направления деятельности казачества, содержал юридическую базу для экономического, социально-культурного, общественно-политического развития казачьего сообщества и способствовал его укреплению.

Новый Указ Президента РК от 21.04.1998 г. устанавливал, что Государственный комитет по делам казачества приравнивается по своему статусу к министерству, что в значительной степени укрепляло статус казачества, его значимость в региональной политике и общественной жизни. Указом было установлено, что в ведении Госкомитета в пределах его компетенции находятся все казачьи общины республики и их структурные подразделения, внесенные в Госреестр Республики Калмыкия. Основными функциями Госкомитета являлись: разработка единой государственной политики возрождения, становления и развития казачества на территории Республики Калмыкия, традиционных форм его самоуправления, исходя из исторических традиций и современных потребностей государства и создания условий для ее реализации; координация деятельности созданных и создаваемых на территории республики казачьих общин, входящих структурными подразделениями в Казачье войско Калмыкии и др. [7].

Таким образом, поэтапное принятие законодательных и иных нормативных актов на региональном уровне в значительной степени расширяло как зону государственного влияния на казачество, так и его возможности на пути возрождения.

На начало 2001 г. в казачьих общинах республики, по сведениям Госкомитета по казачеству РК, состояло 30 тысяч казаков и членов их семей. В КВК было зарегистрировано 7150 казаков, готовых нести государственную и иную службу [9]. Целенаправленная работа проводилась Казачьим войском Калмыкии по военно-патриотическому и нравственному воспитанию среди молодежи с привлечением ветеранов Великой Отечественной войны, священнослужителей буддийской и православной религий. Активное участие принимали казаки в открытии памятника Герою Советского Союза Б.Б. Городовикову в Городовиковском районе, а также погибшим воинам 22-й Донской казачьей бригады специального назначения Северо-Кавказского военного округа, где ныне служат казаки - уроженцы Калмыкии [15]. Была совершена поездка и посещение воинского мемориала героямземлякам - уроженцам Калмыцкого и Зимовниковского районов Ростовской области. Большая работа велась Госкомитетом по подготовке и проведению 60-летия со времени кровопролитных боев 110-й Отдельной Калмыцкой кавалерийской дивизии на Дону в районе хутора Ажиново Богаевского района Ростовской области [15]. Госкомитет строил свою работу во взаимодействии с атаманским правлением КВК, оказывал содействие подразде- 
лениям КВК по развитию предпринимательской деятельности, привлекая для работы в казачьи хозяйственные структуры опытных специалистов - экономистов, юристов, вел работу по организации единой финансово-экономической базы Войска и казачьих производственных предприятий. В республике были созданы и работали коммерческие предприятия: ООО Торговый дом «Центральный Казачий рынок», ТОО «Казачий стан», ТОО «Казачья воля», ТОО «Казачий торговый дом», кооператив «Кючн», казачье фермерское хозяйство «Байр» и др. По решению Войскового круга и Совета атаманов КВК атаманские правления округов, станиц и хуторов принимали активное участие в охране общественного порядка и безопасности граждан в населенных пунктах районов и г. Элисте. В республике были созданы и действовали 315 казачьих дружин, в которых насчитывалось 2500 человек. Одним из важных направлений в их деятельности была работа с трудновоспитуемыми подростками. Дружинники проводили рейды, привлекали ребят к занятиям в спортивных секциях, организовывали для подростков военнопатриотические клубы и др. [8].

Активное участие казаки принимали в мероприятиях, посвященных Дню Победы, проводили строевые смотры, концерты казачьих художественных коллективов, шефствовали над воинскими мемориалами и захоронениями. Руководство Госкомитета совместно с КВК организовывало циклы передач на телевидении и радио по истории казачества, его участию в защите Отечества. КВК и Госкомитет взаимодействовали с другими казачьими обществами России, участвовали в проводимых ими мероприятиях. Так, руководство КВК и Госкомитета принимали участие в заседаниях Совета атаманов Кубанского казачьего войска, Ставропольского казачьего войска, Черноморского казачьего войска (г. Тирасполь), Запорожского казачьего войска Союза казаков Украины и Пятигорского отдела Терского казачьего войска, на которых обменивались опытом работы, планировали совместные мероприятия, подписывали договора о сотрудничестве [16].

Следует отметить, что казачество Калмыкии на протяжении всего своего возрожденческого движения, взаимодействуя и со- трудничая с различными казачьими обществами и другими объединениями казаков России, оставалось самостоятельным сообществом. Лишь в мае 2006 г., обсудив вопросы дальнейшего развития, на основании решения Большого круга, в целях укрепления единства в движении за возрождение, казачество Калмыкии приняло решение о вхождении в состав реестровой организации Войскового казачьего общества «Всевеликого войска Донского» (далее - ВКО «ВВД») в качестве Отдельного Калмыцкого казачьего округа (далее ККО), что стало началом нового, поворотного, этапа в его деятельности. Через столетие потомки донских казаков и калмыков-казаков вновь объединились для возрождения славной истории своих предков, древней культуры и вековых традиций казачьего воинства. Калмыцкий казачий округ имеет свое знамя, на обороте которого вышит герб войскового казачьего общества «Всевеликое войско Донское». На лицевой стороне цветовой фон повторяет триколор исторического флага ВВД - синий, желтый и алый. Это национальные цвета издревле живущих на Донской земле донских казаков, калмыков и русских крестьян. Летом 2008 г. состоялось торжественное освящение знамени Отдельного Калмыцкого казачьего округа ВКО «ВВД», которое провели буддийские священнослужители и архиепископ Элистинский и Калмыцкий владыка Зосима. Церемония проходила при большом стечении жителей Элисты, казаков и гостей праздника. Торжество завершилось фестивалем казачьей культуры «В семье единой».

В настоящее время ККО во главе с атаманом Э.Н. Манжиковым видит свою задачу в реализации «Концепции государственной политики Российской Федерации в отношении российского казачества», принятой 2 июля 2008 г. (№ 1355), и «Концепции развития казачества в Республике Калмыкия до 2020 года», утвержденной Распоряжением Правительства РК от 22 августа 2013 года. В целях выполнения данных основополагающих документов по развитию казачества в республике разработан план мероприятий по привлечению членов казачьих обществ к несению государственной и иной службы, созданию условий для их дальнейшего развития. В Правительстве была создана рабочая группа под руководством Пред- 
седателя Правительства И.А. Зотова, которая координировала и решала задачи, связанные с реализацией проектов по вопросам возрождения казачества. В числе приоритетных задач были военно-патриотическое и нравственное воспитание будущего казачества, открытие казачьих классов в образовательных учреждениях. В настоящее время в Калмыкии действуют пять таких классов, два из них находятся в Русской национальной гимназии, два других расположены в СШ № 2, а один - в с. Троицкое. В соответствии с Распоряжением Правительства РК от 31.10.2013 г. № 358-р на базе казенного образовательного учреждения «Городовиковский детский дом» в г. Городовиковске был открыт Казачий кадетский корпус, что явилось знаковым событием в деле возрождения казачества. Это учебное заведение стало первым учреждением данного профиля, в стенах которого юные кадеты обучаются по общеобразовательной программе основного среднего общего образования и дополнительной образовательной программе в целях подготовки их к несению государственной или иной службы российского казачества. В качестве важнейшей составляющей учебно-воспитательного процесса определено сохранение исторических, культурных и духовных традиций казачества. Учащиеся проходят строевую подготовку и обучаются рукопашному бою, игре на духовых и народных инструментах, пению казачьих песен, постигают искусство танца и верховой езды [19].

Одной из важных составляющих возрождения казачества являются сохранение и развитие культуры, традиций и обычаев предков, воспитание уважения к другим народам. Делегация ККО и казачий ансамбль «Джиргал» принимали участие в проходивших в Москве V Общероссийском Круге Союза казаков и фестивале казачьих творческих коллективов, посвященных 10-летию Союза. В республике стало традиционным ежегодное проведение фестиваля «В семье единой», ставшего привлекательным для участия в нем коллективов из других регионов, представляющих казачью культуру.

Активную работу по исследованию и осмыслению феномена казачества ведут ученые Калмыкии. История казачества отраже- на в ряде монографических трудов исследователей, в том числе фундаментальной трехтомной «Истории Калмыкии с древнейших времен до наших дней». Движению казачества за возрождение посвящены научные статьи, публикации в СМИ, как региональных, так и федеральных. На телевидении, радио часто выступают лидеры движения казачества. В Калмыцком государственном университете им. Б.Б. Городовикова, научных учреждениях республики регулярно проводятся конференции и круглые столы, посвященные различным аспектам истории казачества и современным тенденциям его развития. В них, наряду с учеными, принимают участие представители казачества и духовенства традиционных конфессий и др.

Результаты. Как показывает проведенное исследование, идея возрождения казачества была активно поддержана калмыкамиказаками, что было обусловлено трехсотлетней историей пребывания их предков в составе Донского и Астраханского казачества. Трагические события Гражданской войны, потеря родных в эмиграции, «расказачивание» и депортация, пребывание не в «казачьем Кругу» не стерли историческую память калмыцкого казачества, не повлияли на его выбор в современный непростой период российской истории. В числе первых в стране оно активно включилось в движение по возрождению казачества.

Процесс развития возрожденческого движения казачества Калмыкии можно разделить на три основных этапа: первый - это конец 1980-х гг. и середина 1990-х годов. В этот период формируется круг единомышленников, сыгравших затем главную роль в создании общественной организации казачества. Второй этап - начиная с середины 1990-х гг. - до середины 2000-х гг., является периодом оформления и создания правовых основ общественной организации, укреплением статуса казачества региона. Третий этап - с середины 2000-х гг. по настоящее время, отмечается активным участием казаков Калмыкии в общественно-политической жизни, вхождением Калмыцкого казачьего округа в состав ВКО «ВВД». Следует отметить, что каждый из этих этапов характеризуется поступательным развитием казачьих обществ Калмыкии в тес- 
ном взаимодействии с органами законодательной и исполнительной власти республики, муниципальными образованиями. За период своего существования казаки сумели завоевать авторитет, заняв активную гражданскую позицию, стать значимой общественно-политической силой в калмыцком обществе, чему способствовало и внимание к казачеству со стороны региональной власти. Возрождение казачества Калмыкии на ранних этапах происходило под знаком идеализации прошлого опыта, но со временем в столкновении с реалиями сегодняшнего дня пришло понимание необходимости соотнесения прошлого с настоящим и выбора целесообразных путей решения проблем. Специфика и особенность движения казачества Калмыкии за возрождение кроется в его истоках, тесно связанных с историческими событиями прошлого столетия. Во-первых, процесс возрождения калмыков-казаков происходит вне их традиционной территории проживания, во-вторых, что важно, объединению удалось собрать в Калмыцкий казачий округ выходцев из различных войск - Донского, Астраханского, Кубанского, Оренбургского, Уральского, Терского и создать обстановку доверия и сотрудничества, в-третьих, отличительной особенностью является мирное сосуществование двух равноправных конфессий в ККО - буддизма и православия, которые традиционно исповедуют казаки Калмыкии. Все это является залогом успеха на пути их возрождения.

\section{ПРИМЕЧАНИЯ}

${ }^{1}$ Публикация подготовлена в рамках реализации Государственного задания ЮНЦ РАН, № госпроекта AAAA-A 19-119011190182-8.

The work was carried out in the framework of implementing the state task of The Southern Scientific Centre of the Russian Academy of Sciences (SSC RAS), state project no. AAAA-A 19-119011190182-8.

2 Личные материалы автора.

\section{СПИСОК ЛИТЕРАТУРЫ}

1. Бугай, Н. Ф. Казачество России: отторжение, признание, возрождение (1917-1990 годы) / Н. Ф. Бугай. - М. : Можайск : Терра, 2000. - 96 с.

2. Временное Положение о Государственном Комитете по делам казачества Республики Кал- мыкия // Национальный архив Республики Калмыкия. - Ф. Р-601. - Оп. 1. - Д. 9. - Л. 2.

3. Гучинова, Э.-Б. М. Этнополитическая ситуация в Калмыкии / Э.-Б. М. Гучинова, С. Д. Таванец // Исследования по прикладной и неотложной этнологии. - М. : Ин-т этнологии и антропологии РАН, 1994. - Док. № 65. - С. 5-16.

4. Джалаева, А. М. Политика России в отношении донских казаков и калмыков в XVII в. // Калмыки в многонациональной России: опыт четырех столетий / А. М. Джалаева. - Элиста : Джангар, 2008. -368 c.

5. Закон Республики Калмыкия «О казачестве» от 23.12.1997 г. № 95-1-3 // Известия Калмыкии. $-1998 .-8$ янв.

6. Илюмжинов, Н. Д. Память живая: документальная и художественная проза / Н. Д. Илюмжинов. - М. : Худ. лит., 2009. - 796 с.

7. Информационный сайт Республики Калмыкия. - Электрон. текстовые дан. - Режим доступа: http://r08.info/07.php (дата обращения: 13.02.2019).Загл. с экрана.

8. Информационная справка о деятельности Государственного комитета по делам казачества Республики Калмыкия // Национальный архив Республики Калмыкия. - Ф. Р-601. - Оп. 1.-Д. 22. - Л. 1.

9. Информационная справка о казачьих общинах в Республике Калмыкия // Национальный архив Республики Калмыкия. - Ф. Р-601. - Оп. 1. Д. 21. - Л. 4.

10. Козлов, А. И. Возрождение казачества: история и современность (эволюция, политика, теория) / А. И. Козлов. - Ростов н/Д : Изд-во Рост. унта, 1995. $-248 \mathrm{c}$.

11. Краснов, П. Н. На внутреннем фронте; В донской станице при большевиках (февраль 1918 г.) ; Всевеликое Войско Донское : сб. воспоминаний генерала Краснова / П. Н. Краснов. - М. : Айрис-Пресс, 2003. - 454 с.

12. Максимов, К. Н. Калмыки в составе Донского казачества (XVII - сер. XX в.) / К. Н. Максимов. - Ростов н/Д : Изд-во ЮНЦ РАН, 2016. -584 с.

13. Матишов, Г. Г. Донские казаки: от опоры самодержавия до жертв большевизма (XVIII$\mathrm{XX}$ вв.). Заметки на полях истории / Г. Г. Матишов. - Ростов н/Д : Изд-во ЮНЦ РАН, 2013. -272 с.

14. Мациевский, Г. О. Казачество современной России: история политической жизни / Г. О. Мациевский. - Старый Оскол : Кириллица, 2012. -402 c.

15. Отчет о проделанной работе Государственным комитетом по делам казачества Республики Калмыкия за I полугодие 2001 г. // Национальный архив Республики Калмыкия. - Р-601. Оп. 1.- Д. 27. - Л. 5.

16. Отчет о проделанной работе Государственным комитетом по делам казачества Республики Кал- 
мыкия за 2000 г. // Национальный архив Республики Калмыкия. - Р-601. - Оп. 1. - Д. 22. - Л. 9.

17. Очерки истории и культуры казачества Юга России : коллектив. моногр. / под ред. Г. Г. Матишова, И. О. Тюменцева. - Волгоград : Волгогр. фил. ФГБОУ ВПО РАНХ И ГС, 2014. - 623 с.

18. Очиров, У. Б. Калмыкия в период Гражданской войны (1917-1920 гг.) / У. Б. Очиров. - Элиста : Джангар, 2006. - 448 с.

19. Петрулевич, И. А. Управление межэтническими взаимодействиями в современной Калмыкии: социально-экономический и политический контекст / И. А Петрулевич // Теория и практика общественного развития. - 2014. - № 21. - С. 34-40.

20. Рвачева, О. В. Движение за возрождение казачества в Калмыкии в конце XX - начале XXI в. / О. В. Рвачева // Вестник Калмыцкого института гуманитарных исследований РАН. - 2016. - № 2. C. 42-49.

21. Рыблова, М. А. Донское казачество: к вопросу об «истоках» и социокультурных трансформациях / М. А. Рыблова // Этнографическое обозрение. - 2010. - № 6. - С. 158-174.

22. Сборник законодательных и нормативных актов о репрессиях и реабилитации жертв политических репрессий. - М. : Республика : Верховный Совет Рос. Федерации, 1993. - 222 с.

23. Таболина, Т. В. Казаки: драма возрождения. 1980-1990-е годы / Т. В. Таболина. - М. : Изд-во Ин-та этнологии и антропологии им. Н.Н. МиклухоМаклая РАН, 1999. - 252 с.

24. Тепкеев, В. Т. Калмыки в Северном Прикаспии во второй трети XVII века: проблемы политических взаимоотношений / В. Т. Тепкеев. - Элиста : Джангар, 2014. - 448 с.

25. Указ Президента Республики Калмыкия «О Государственном Комитете по делам казачества Республики Калмыкия» от 6 июня 1994 г. № 107 // Национальный архив Республики Калмыкия. Ф. Р-601. - Оп. 1. - Д. 2. - Л. 1.

26. Шовунов, К. П. Калмыки в составе российского казачества (вторая половина XVII XIX в.) / К. П. Шовунов. - Элиста : Изд-во Калмыц. ин-та обществен. наук, 1992. - 319 с.

27. Юрченко, И. Ю. Тематика научных публикаций по проблеме казачества Юга России в ведущих российских журналах (2005-2009) / И. Ю. Юрченко // Культурная жизнь Юга России. - 2011. - № 2 (40). - С. 38-43.

28. Peretyatko, A. Y. Higher and secondary education of the Don Cossacks in the context of the epoch: the time of the great reforms / A. Y. Peretyatko, T. E. Zulfugarzade // European Journal of Contemporary Education. - 2017. - № 6(2). - P. 367-377.

29. Toje, H. Cossack identity in the new Russia: Kuban Cossack revival and local politics
/ H. Toje // Europe-Asia Studies. - 2006. - № 58 (7). P. $1057-1077$.

\section{REFERENCES}

1. Bugay N.F. Kazachestvo Rossii: ottorzhenie, priznanie, vozrozhdenie (19171990 gody) [The Cossacks of Russia: Rejection, Recognition, Revival (1917-1990)]. Moscow, Mozhaysk, Terra Publ., 2000. 96 p.

2. Vremennoe Polozhenie o Gosudarstvennom Komitete po delam kazachestva Respubliki Kalmykiya [Temporary Regulations on the State Committee for Cossack Affairs of the Republic of Kalmykia]. Natsionalnyy arkhiv Respubliki Kalmykiya [National Archive of the Republic of Kalmykia], F. P-601, Op. 1, D. 9, L. 2 .

3. Guchinova E.-B.M., Tavanets S.D. Etnopoliticheskaya situatsiya $v$ Kalmykii [Ethnopolitical Situation in Kalmykia]. Issledovaniya po prikladnoy i neotlozhnoy etnologii [Studies in Applied and Emergency Ethnology]. Moscow, Institut etnologii i antropologii RAN, 1994, doc. no. 65, pp. 5-16.

4. Dzhalaeva A.M. Politika Rossii v otnoshenii donskikh kazakov i kalmykov v XVII v. [Russia's Policy Towards the Don Cossacks and Kalmyks in the $17^{\text {th }} \mathrm{c}$.]. Kalmyki v mnogonatsionalnoy Rossii: opyt chetyrekh stoletiy [Kalmyks in Multinational Russia. Experience of Four Centuries]. Elista, Dzhangar Publ., 2008. 368 p.
5. Zakon Respubliki Kalmykiya «O kazachestve» ot 23.12.1997 g. № 95-1-3 [Law of the Republic of Kalmykia "On the Cossacks" (Dated December 23, 1997, no. 95-1-3]. Izvestiya Kalmykii, 1998, January 8.

6. Ilyumzhinov N.D. Pamyat zhivaya: dokumentalnaya $i$ khudozhestvennaya proza [Live Memory. Documentary and Artistic Prose]. Moscow, Khudozhestvennaya literatura Publ., 2009. 796 p.

7. Informatsionnyy sayt Respubliki Kalmykiya [Information Website of the Republic of Kalmykia]. URL: http://r08.info/07.php (accessed 13 February 2019).

8. Informatsionnaya spravka o deyatelnosti Gosudarstvennogo komiteta po delam kazachestva Respubliki Kalmykiya [Information Note on the Activities of the State Committee for Cossack Affairs of the Republic of Kalmykia]. Natsionalnyy arkhiv Respubliki Kalmykiya [National Archive of the Republic of Kalmykia], F. P- 601, Op. 1, D. 22, L. 1.

9. Informatsionnaya spravka o kazach'ikh obshchinakh v Respublike Kalmykiya [Information Note on the Cossack Communities in the Republic of Kalmykia]. Natsionalnyy arkhiv Respubliki Kalmykiya [National Archive of the Republic of Kalmykia], F. P- 601, Op.1, D. 21, L. 4. 
10. Kozlov A.I. Vozrozhdenie kazachestva: istoriya i sovremennost (evolyutsiya, politika, teoriya) [Revival of the Cossacks. History and Modernity (Evolution, Politics, Theory)]. Rostov-on-Don, Izd-vo Rostovskogo universiteta, 1995. 248 p.

11. Krasnov P.N. Na vnutrennem fronte; $V$ donskoy stanitse pri bolshevikakh (fevral 1918 g.); Vsevelikoe Voysko Donskoe: sb. vospominaniy generala Krasnova [On the Domestic Front; In the Don Stanitsa with the Bolsheviks (February 1918); The Great Don Host. Collection of General Krasnov's Memories]. Moscow, Iris-Press Publ., 2003. 454 p.

12. Maksimov K.N. Kalmyki v sostave Donskogo kazachestva (XVII-ser. XX v.) [The Kalmyks as Part of the Don Cossacks $\left(17^{\text {th }}-\operatorname{Mid} 20^{\text {th }}\right.$ c. $\left.)\right]$. Rostov-on-Don, Izd-vo YuNTs RAN, 2016. 584 p.

13. Matishov G.G. Donskie kazaki: ot opory samoderzhaviya do zhertv bolshevizma (XVIII$X X v v$.). Zametki na polyakh istorii [Don Cossacks. From Supporting the Autocracy to the Victims of Bolshevism $\left(18^{\text {th }}-20^{\text {th }}\right.$ c. $)$ ]. Rostov-on-Don, Izd-vo YuNTs RAN, 2013. 272 p.

14. Matsievskiy G.O. Kazachestvo sovremennoy Rossii: istoriya politicheskoy zhizni [The Cossacks of Modern Russia. History of the Political Life]. Stary Oskol, Kirillitsa, 2012.402 p.

15. Otchet o prodelannoy rabote Gosudarstvennym komitetom po delam kazachestva Respubliki Kalmykiya za I polugodie 2001 g. [Report on the Work Done by the State Committee for Cossack Affairs of the Republic of Kalmykia for the First Half of 2001]. Natsionalnyy arkhiv Respubliki Kalmykiya [National Archive of the Republic of Kalmykia], P-601, Op. 1, D.27, L. 5.

16. Otchet o prodelannoy rabote Gosudarstvennym komitetom po delam kazachestva Respubliki Kalmykiya za 2000 g. [Report on the Work Done by the State Committee for Cossack Affairs of the Republic of Kalmykia for 2000]. Natsionalnyy arkhiv Respubliki Kalmykiya [National Archive of the Republic ofKalmykia], P-601, Op. 1, D. 22, L. 9.

17. Matishov G.G., Tyumentsev I.O., eds. Ocherki istorii i kultury kazachestva Yuga Rossii: kollektiv. monogr. [Essays on the History and Culture of the Cossacks of the South of Russia. Collective Monograph]. Volgograd, Volgogradskiy filial FGBOU VPO RANKhIGS, 2014. 623 p.

18. Ochirov U.B. Kalmykiya $v$ period Grazhdanskoy voyny (1917-1920 gg.) [Kalmykia During the Civil War (1917-1920)]. Elista, Dzhangar Publ., 2006. 448 p.

19. Petrulevich I.A. Upravlenie mezhetnicheskimi vzaimodeystviyami v sovremennoy Kalmykii: sotsialnoekonomicheskiy i politicheskiy kontekst [Management of Interethnic Interactions in Modern Kalmykia]. Teoriya i praktika obshchestvennogo razvitiya [Theory and Practice of Social Development], 2014, no. 21, pp. 34-40.
20. Rvacheva O.V. Dvizhenie za vozrozhdenie kazachestva v Kalmykii v kontse XX - nachale XXI v. [Movement for the Revival of the Cossacks in Kalmykia in the Late $20^{\text {th }}-$ Early $21^{\text {st }}$ c.]. Vestnik Kalmytskogo instituta gumanitarnykh issledovaniy RAN [Oriental Studies], 2016, no. 2, pp. 42-49.

21. Ryblova M.A. Donskoe kazachestvo: k voprosu ob «istokakh» i sotsiokulturnykh transformatsiyakh [The Don Cossacks. On the Issue of "Origins" and Social and Cultural Tansformations]. Etnograficheskoe obozrenie, 2010, no. 6, pp. 158-174.

22. Sbornik zakonodatelnykh i normativnykh aktov o repressiyakh $i$ reabilitatsii zhertv politicheskikh repressiy [Collected Enactments and Regulations on Political Repressions and Rehabilitation of Their Victims]. Moscow, Respublika Publ., Verkhovnyy Sovet Rossiyskoy Federatsii, 1993. 222 p.

23. Tabolina T.V. Kazaki: drama vozrozhdeniya. 1980-1990-e gody [Cossacks. Drama of Revival. 1980s 1990s]. Moscow, Izd-vo Instituta etnologii i antropologii im. N.N. Miklukho-Maklaya RAN, 1999. 252 p.

24. Tepkeev V.T. Kalmyki v Severnom Prikaspii vo vtoroy treti XVII veka: problemy politicheskikh vzaimootnosheniy [The Kalmyks in the Northern Caspian Region in the Second Third of the $17^{\text {th }}$ Century. Problems of Political Relations]. Elista, Dzhangar Publ., 2014. 448 p.

25. Ukaz Prezidenta Respubliki Kalmykiya «O Gosudarstvennom Komitete po delam kazachestva Respubliki Kalmykiya» ot 6 iyunya 1994 g. № 107 [Decree of the President of the Republic of Kalmykia "On the State Committee for Cossack Affairs of the Republic of Kalmykia" of June 6, 1994, no. 107]. Natsionalnyy arkhiv Respubliki Kalmykiya [National Archive of the Republic of Kalmykia], F. P-601, Op. 1, D. 2, L. 1.

26. Shovunov K.P. Kalmyki v sostave rossiyskogo kazachestva (vtoraya polovina XVII $X I X v$.) [The Kalmyks as a Part of the Russian Cossacks (Late $17^{\text {th }}-19^{\text {th }} \mathrm{c}$. Elista, Izd-vo Kalmytskogo instituta obshchestvennykh nauk, 1992. 319 p.

27. Yurchenko I.Yu. Tematika nauchnykh publikatsiy po probleme kazachestva Yuga Rossii v vedushchikh rossiyskikh zhurnalakh (2005-2009) [Subject-Matter of Scientific Publications on the Issue of the Cossacks of the South of Russia in Leading Russian Journals (2005-2009)]. Kulturnaya zhizn Yuga Rossii [Cultural Studies Russian South], 2011, no. 2 (40), pp. 38-43.

28. Peretyatko A.Y., Zulfugarzade T.E. Higher and Secondary Education of the Don Cossacks in the Context of the Epoch: The Time of the Great Reforms. European Journal of Contemporary Education, 2017, no. 6(2), pp. 367-377.

29. Toje H. Cossack Identity in the New Russia: Kuban Cossack Revival and Local Politics. EuropeAsia Studies, 2006, no. 58 (7), pp. 1057-1077. 
Н.Г. Очирова. Региональные особенности возникновения казачьих общественных объединений в России

\section{Information about the Author}

Nina G. Ochirova, Candidate of Sciences (Politics), Leading Researcher, Department of Humanitarian Studies, Federal Research Centre The Southern Scientific Centre of the Russian Academy of Sciences (SSC RAS), Chekhov St., 41, 344006 Rostov-on-Don, Russian Federation, ngochirova00@mail.ru, https://orcid.org/0000-0002-7351-0250

\section{Информация об авторе}

Нина Гаряевна Очирова, кандидат политических наук, ведущий научный сотрудник отдела гуманитарных исследований, Федеральный исследовательский центр Южный научный центр Российской академии наук, просп. Чехова, 41, 344006 г. Ростов-на-Дону, Российская Федерация, ngochirova00@mail.ru, https://orcid.org/0000-0002-7351-0250 